\title{
SYMPTOM PROFILE AND CO-MORBID PSYCHIATRIC DISORDERS IN MENTALLY RETARDED CHILDREN AND ADOLESCENTS
}

\author{
Ojha S $\mathbf{P}^{1}$, Pokharel $\mathbf{A}^{2}$, Nepal $\mathbf{M} \mathbf{K}^{1}$ \\ Regmi S K ${ }^{1}$, Koirala N R ${ }^{1}$, Sharma S $\mathbf{C}^{3}$
}

\section{ABSTRACT}

A retrospective study of 52 children and adolescent subjects suffering from mental retardation who attended in the Child Guidance Clinic in the Department of Psychiatry OPD, Teaching Hospital, Katmandu, Nepal. They were brought to the OPD with various symptoms. It was found that the number of male patients were 35 compared to 17 female with male female ratio of $2: 1$. The mean age of male patients was $9.19+$ 3.55 years where as the mean age of female patients was $9.91+9.99$ years. General Practitioner and Pediatrician referred majority of them. The commonest symptom with which the patients presented to the hospital was aggressive behavior $(28 \%)$ while 14 patients $(26.9 \%)$ presented with speech related problems. Of the 52 patients who presented in Child Guidance Clinic, 11 patients had comorbid psychiatric problems. It was found that 4 patients had hyperkinetic disorders, 3 patients had disorders of psychological development, 1 patient each had post encephalitic sequel, depressive disorder, somatization disorder and eating disorder.

Key words: Mental retardation, Psychiatric disorder, Child Guidance Clinic

1. Department of Psychiatry, Institute of Medicine.

2. Mental Hospital, Lagankhel.

3. Clinical Psychologist, Kathmandu Medical College.

Address for correspondence : $\quad$ Dr. Saroj Prasad Ojha, MD (Psychiatry),

Department of Psychiatry, Institute of Medicine

Maharajgunj, Kathmandu, Nepal. 


\section{INTRODUCTION}

Mental retardation is generally defined in terms of both social and intellectual functioning. Using either criterion can lead to unfortunate results. In the past, the use of social criteria clearly led to abuse. Nevertheless, it is unsatisfactory to define mental retardation in terms of intelligence alone. Social criteria must be included, since a clinical distinction must be made between people who can lead a normal or near-normal life and these who can not.

DSM IV ${ }^{1}$ defines mental retardation as a 'significantly sub-average general intellectual functioning in at least two of the following skill areas: communication, self care, home living, social/interpersonal skills used for community resources, self direction, functional academic skills, work, leisure, health and safety' and having an onset before the age 18 .

The incidence of mental retardation has fallen because of the improvement of antenatal and neonatal care, but at the same time the prevalence has not changed because the patients are living longer, particularly those with down's syndrome. ${ }^{2}$ In $1929,{ }^{3}$ a study in U. K. showed that the prevalence of mental retardation was 27 per thousand, and the prevalence of moderate and severe retardation (IQ less than50) was 3.7 per thousand. Subsequent studies in many countries have generally shown that, in the population aged 15-19, the prevalence of moderate and severe retardation is about $3.0-4.0$ per $1000 .^{2}$

Children and adolescents with a mental retardation are at a greater risk of developing psychiatric disorders. As shown in various studies, children with mental handicap were 4 to 7 times more likely to have a psychiatric disorder than the general population, depending upon the severity of the handicap. ${ }^{4}$ In the western countries, over the last 20 years major changes have taken place in the services provided for children and adolescent with a mental retardation. In Nepal, there have been no such major changes for this group of people.

\section{METHODOLOGY}

The aim of present work was to study the sociodemographic characteristics, symptom profile and psychiatric co-morbidity of children and adolescents attending the Child Guidance Clinic, Psychiatry O.P.D. at T.U.T.H. over a period of 2.75 years. It was a retrospective analysis of case records. The samples for the study were the case records of all patients attending the clinic, who received the diagnosis Mental Retardation. A self-designed Performa was used to record the socio-demographic data and clinical information. Diagnoses were made according to ICD-10. The information was kept confidential. Data analysis was done in SPSS version 7.5.

\section{RESULTS}

Out of total 52 subjects suffering from mental retardation, 35 (67.3\%) were males. Majority were

Table 1

Mental and behavioural symptoms vs. sex.

\begin{tabular}{|c|c|c|c|}
\hline \multirow[t]{2}{*}{ Main symptoms } & \multicolumn{2}{|c|}{ Sex } & \multirow[t]{2}{*}{ Total } \\
\hline & Male & Female & \\
\hline Aggressive behavior & 10 & 5 & $\begin{array}{c}15 \\
(28.8 \%)\end{array}$ \\
\hline Bed wetting & 0 & 1 & $\begin{array}{c}1 \\
(1.9 \%)\end{array}$ \\
\hline Speech related problem & 8 & 6 & $\begin{array}{c}14 \\
(26.9 \%)\end{array}$ \\
\hline Slow in actions & 4 & 0 & $\begin{array}{c}4 \\
(7.7 \%)\end{array}$ \\
\hline Poor academic performance & 8 & 5 & $\begin{array}{c}13 \\
(25 \%)\end{array}$ \\
\hline Fainting attacks & 2 & 0 & $\begin{array}{c}2 \\
(3.8 \%)\end{array}$ \\
\hline Headache / somatic problems & 2 & 0 & $\begin{array}{c}2 \\
(3.8 \%)\end{array}$ \\
\hline Vomiting following meal & 1 & 0 & $\begin{array}{c}1 \\
(1.9 \%) \\
\end{array}$ \\
\hline & $\begin{array}{c}35 \\
(67.3 \%) \\
\end{array}$ & $\begin{array}{c}17 \\
(32.7 \%) \\
\end{array}$ & 52 \\
\hline
\end{tabular}


in the age group $6-12$ years $(\mathrm{N}=28,53.8 \%)$, followed by age up-to 6 years $(\mathrm{N}=14,26.9 \%)$ and more than 12 years $(\mathrm{N}=10,19.2 \%)$. The average age of male patients was $9.19+3.55$ years, of female patients was $9.91+3.99$ years and for all, it was $9.42+3.67$ years. Thirty one $(59.5 \%)$ came from Table 2

Mental and behavioural symptoms vs. age-group.

\begin{tabular}{|l|c|c|c|c|}
\hline \multirow{2}{*}{ Main symptoms } & \multicolumn{3}{|c|}{ Age-group (Years) } & \multirow{2}{*}{ Total } \\
\cline { 2 - 4 } & $\mathbf{6}$ & $\mathbf{6 - 1 2}$ & $\mathbf{1 2}$ & \\
\hline $\begin{array}{l}\text { Aggressive } \\
\text { behavior }\end{array}$ & 5 & 6 & 4 & $\begin{array}{c}15 \\
(28.8 \%)\end{array}$ \\
\hline Bed wetting & 0 & 0 & 1 & $\begin{array}{c}1 \\
(1.9 \%)\end{array}$ \\
\hline $\begin{array}{l}\text { Speech related } \\
\text { problems }\end{array}$ & 5 & 5 & 4 & $\begin{array}{c}14 \\
(26.9 \%)\end{array}$ \\
\hline Slow in actions & 2 & 2 & 0 & $\begin{array}{c}4 \\
(7.7 \%)\end{array}$ \\
\hline $\begin{array}{l}\text { Poor academic } \\
\text { performance }\end{array}$ & 1 & 11 & 1 & $\begin{array}{c}13 \\
(25 \%)\end{array}$ \\
\hline $\begin{array}{l}\text { Fainting attacks } \\
\text { Headache / } \\
\text { somatic problems }\end{array}$ & 0 & 2 & 0 & $\begin{array}{c}2 \\
(3.8 \%)\end{array}$ \\
\hline $\begin{array}{l}\text { Vomiting } \\
\text { following meal }\end{array}$ & 0 & 1 & 0 & $\begin{array}{c}2 \\
(3.8 \%)\end{array}$ \\
\hline \multicolumn{2}{|l|}{14} & 28 & 10 & 52 \\
\hline
\end{tabular}

within the Kathmandu valley. Only 22 (42.3\%) subjects attended school, of which only $3(5.7 \%)$ attended special schools. Majority were referred by general practitioners $(\mathrm{N}=19,36.3 \%)$, followed by pediatricians $(\mathrm{N}=11,21.2 \%)$, parents themselves $(\mathrm{N}=10,19.2 \%)$, psychiatrists $(\mathrm{N}=7,13.4 \%)$ and relatives $(\mathrm{N}=5,9.6 \%)$.

Table 3

Mental and behavioural symptoms vs. grade of mental retardation.

\begin{tabular}{|l|c|c|c|c|c|}
\hline \multirow{2}{*}{ Main symptoms } & \multicolumn{4}{|c|}{ Grade of retardation } & Total \\
\cline { 2 - 5 } & Mild & Moderate & Severe & Profound & \\
\hline $\begin{array}{l}\text { Aggressive } \\
\text { behavior }\end{array}$ & 8 & 3 & 2 & 2 & $\begin{array}{c}15 \\
(28.8 \%)\end{array}$ \\
\hline Bed wetting & 0 & 1 & 0 & 0 & $\begin{array}{c}1 \\
(1.9 \%)\end{array}$ \\
\hline $\begin{array}{l}\text { Speech related } \\
\text { problem }\end{array}$ & 13 & 1 & 0 & 0 & $\begin{array}{c}14 \\
(26.9 \%)\end{array}$ \\
\hline Slow in actions & 2 & 1 & 1 & 0 & $\begin{array}{c}4 \\
(7.7 \%)\end{array}$ \\
\hline $\begin{array}{l}\text { Poor academic } \\
\text { performance }\end{array}$ & 12 & 1 & 0 & 0 & $\begin{array}{c}13 \\
(25 \%)\end{array}$ \\
\hline $\begin{array}{l}\text { Fainting attacks } \\
\text { Headache / } \\
\text { somatic problems }\end{array}$ & 2 & 0 & 0 & 0 & $\begin{array}{c}2 \\
(3.8 \%)\end{array}$ \\
\hline $\begin{array}{l}\text { Vomiting } \\
\text { following meal }\end{array}$ & 1 & 0 & 0 & 0 & $\begin{array}{c}2 \\
(3.8 \%)\end{array}$ \\
\hline & 40 & 7 & 3 & 2 & $(1.9 \%)$ \\
\hline
\end{tabular}

Most of the subjects suffered from Mild Mental Retardation ( $\mathrm{N}=40,76.9 \%)$, followed by Moderate $(\mathrm{N}=7,13.5 \%)$, Severe $(\mathrm{N}=3,5.8 \%)$ and Profound $(\mathrm{N}=2,3.8 \%)$.

\section{Table 4}

Co-morbid psychiatric disorders.

\begin{tabular}{|l|c|c|c|}
\hline \multirow{2}{*}{ Co-morbid conditions } & \multicolumn{2}{|c|}{ Sex } & \multirow{2}{*}{ Total } \\
\cline { 2 - 4 } & Male & Female & \\
\hline Post-encephalitic sequelae & 0 & 1 & 1 \\
\hline Depressive disorder & 0 & 1 & 1 \\
\hline Somatization disorder & 1 & 0 & 1 \\
\hline Eating disorder & 1 & 0 & 1 \\
\hline $\begin{array}{l}\text { Disorder of psychological } \\
\text { development }\end{array}$ & 1 & 2 & 3 \\
\hline Hyperkinetic disorders & 3 & 1 & 4 \\
\hline & 6 & 5 & 11 \\
\hline
\end{tabular}

Tables 1, 2 and 3 describe various symptoms with which these children and adolescents were brought to the clinic and their relation to sex, age group and grade of mental retardation respectively. Table 4 illustrates co-morbid psychiatric conditions in these children and adolescents. There were 11 $(21.2 \%)$ subjects which received co-morbid psychiatric diagnosis, the largest group among these being hyperkinetic disorder.

\section{DISCUSSION}

Although it is difficult to identify Psychiatric disorders among mentally retarded people, estimates of the prevalence of disease among them are higher than in the general population. In the Isle of weight study children with mental retardation were between 3 to 4 times more likely to have psychiatric disorder than the general population. ${ }^{5}$ Children with a physical handicap, especially where the brain is affected, are also at an increased risk of psychiatric disorder. ${ }^{6}$ Among severely retarded children psychotic disorders was found $50 \%$ compared with $6.6 \%$ in the general population. In a survey, Borthwick-Duffy ${ }^{7}$ found that the rates of psychiatric disorder are higher among mentally retarded people than in general population. 
Among people with mild mental retardation, the ranges of psychiatric syndromes are similar to that in the people of normal range. Among people with moderate and severe retardation, most surveys have found that about half have psychiatric disorder with the highest rates among those most profoundly retarded ${ }^{8}$. Among these group of people, certain kinds of disease are especially frequent, including bedwetting, abnormal behavior like stereotypes, self injuries, pervasive developmental disorder, hyperactivity.

This study is concerned with all the children and adolescents with different degree of mental retardation referred by pediatrician, physicians, psychiatrists or brought by parents or relatives to the child guidance clinic of the Department of Psychiatry of a teaching hospital. The relationship between the high prevalence of psychiatric problems in individuals of mental retardation is not a simple one (Chiefly due to brain damage) and many other factors may play their parts.

In the study there is a relationship between IQ and behavior problems like restless, agitated, disrobed, self-injury. Out of five severe and profound retarded children and adolescents 4 were having behavioral problems in comparison to 8 out of 40 mild retarded children. This may be in part because greater intellectual capacity makes social adaptation easier and showing less deviant behavior.

The developmental immaturity of retarded children can adversely affect their language and other social skills in comparison with those of their peers. These differences, and their delay in achieving motor skills are additional handicaps which may predispose to speech related problems, slow in action, walking problems.

Educational failure is associated with psychiatric disorder among mentally retarded, a finding of Isle of Weigh study ${ }^{9}$. As a group children of low IQ have poor academic performance and difficulty in learning than other children which leads to long standing failure at school. This may be the one of the contributing factor for the development of psychiatric disorder among them.

Besides, there are many other factors, which may play their parts for the development of different symptoms profile and comorbid psychiatric disorders in mentally retarded children and adolescents. Social factors such as parental rejection attitudes, hostile, depriving, rejecting attitudes by other peers affect both intellectual development and emotional stability or development of mental health. Institutionalization, adverse environment can adversely affect the intellectual development and emotional growth. Organic brain disease with epilepsy which may be present in many mentally retarded children is associated with an increased incidence of psychiatric disorder especially contribute behavioral problems.

\section{REFERENCES}

1. American psychiatric Association. Diagnostic and statistical manual of mental disorders. Washington, DC: American Psychiatric Press; 1994.

2. Gelder M, Gath D, Mayou R, Cowen P. Oxford Textbook of Psychiatry, Edn. 3, Somerset: Oxford University Press; 1996.

3. Lewis EO. Report on an investigation into the incidence of mental deficiency in 6 areas. 192527. In Report of the mental deficiency committee, Part IV. HMSO, London: 1929.

4 Cottrell D, Black D, Kaplan T, Jezzard R. Liaison: Child and adblescent psychiatric. Seminar in Child and Adolescent Psychiatry, 1993; 13: 249-275.

5. Rutter M, Tizard T, Whitmore K. Education, Health and Behavior. London: Longman; 1970.

6. Siedel UP, Chadwick O, Rutter M. Psychological disorders in crippled children: a comparative study of children with \& without brain damage. Developmental medicine and Child Neurology. 1975; 17: 563-573.

7. Borthwick-Duffy SA. Epidemiology and prevalence of Psychopathology in people with mental retardation. Journal of Consulting and Clinical Psychology. 1994; 62 (1) : 17-27.

8. Scott S. Mental Retardation. In: Child and adolescent psychiatry: Modern approaches, Edn 3, (M.Rutter, E. Taylor and L.Husov) eds. Blackwell Scientific Publication, Oxford; 1994: pp. 616-46.

9. Rutter M. 'Auststic children: Infancy to adulthood' . Seminar in Psychiatry. 1970; 435-450. 